\title{
De beroepseed voor accountants nader bezien
}

\section{Eva Eijkelenboom}

SAMENVATTING Mei 2016 stemmen de leden van de Koninklijke Nederlandse Beroepsorganisatie van Accountants (NBA) over de beroepseed voor accountants. De invoering van een beroepseed voor accountants is nieuw voor het beroep en levert discussies op over de wenselijkheid en inhoud van de beroepseed. Tot op heden is in deze discussies onderbelicht gebleven dat er ongeveer een eeuw geleden al is gesproken over de beroepseed door de leden van de voorloper van de NBA, het Nederlandsch Instituut voor Accountants. In dit artikel wordt het accountantsverleden rondom de beroepseed nader belicht. Ook worden naar voren gebrachte argumenten uit de huidige discussie nader onderbouwd met juridische literatuur. Betoogd wordt dat de beroepseed voor accountants in theorie meerwaarde kan bieden, maar in de praktijk zijn waarde zal moeten bewijzen.

\section{RELEVANTIE VOOR DE PRAKTIJK Dit artikel geeft inzicht in de historische redenen voor het afwijzen van de eed. Het artikel geeft de hedendaagse accountant daarmee aanvullende informatie die behulpzaam kan zijn bij het bepalen van zijn of haar standpunt over de beroepseed.}

\section{Inleiding}

Op donderdag 25 september 2014, de dag die door de media werd geduid als 'Freaky Thursday', werden drie voor het accountantsberoep relevante rapporten gepubliceerd. De Autoriteit Financiële Markten (AFM) publiceerde haar resultaten van het onderzoek naar de kwaliteit bij de Big-4 accountantsorganisaties (AFM, 2014). De evaluatie van de Wet toezicht accountantsorganisaties (Wta) werd openbaar gemaakt (Eijkelenboom \& Hijink, 2014) en tevens kwam de Werkgroep 'Toekomst accountantsberoep' met 53 verander- en verbetermaatregelen voor de accountantssector gebundeld in het rapport 'In het publiek belang' (Werkgroep 'Toekomst Accountantsberoep', 2014). De allereerste maatregel uit dit rapport, maatregel 1.1, ziet op de invoering van een beroepseed voor accountants die afgelegd moet worden bij inschrijving van de accountant in het accountantsregister. De beroepseed heeft als doel om 'zowel intern als extern duidelijk te communiceren waar het beroep voor staat en welke mindset, cultuur en gedrag van iedere accountant wordt verwacht' (Werkgroep 'Toekomst Accountantsberoep', p. 11).

De NBA heeft de taak gekregen om een voortrekkersrol te vervullen in de totstandbrenging van de beroepseed. Uit de NBA Monitor 'Publiek Belang'1 volgt dat de NBA op het moment van schrijven de mogelijkheid tot regelgeving heeft uitgezocht en een concepttekst voor de beroepseed heeft opgesteld waarover in de zomer van 2015 een consultatie en publiek debat heeft plaatsgevonden. Uiterlijk in mei 2016 wordt de uitwerking van de eed voorgelegd aan de Algemene Ledenvergadering, waarna in juli 2016 de regelgeving in werking moet treden. Het streven is dat alle NBA-leden in januari 2017 de eed hebben afgelegd. ${ }^{2}$

Van idee naar uitvoering in twee jaar tijd zou een voortvarende implementatie van de beroepseed zijn. Het is daarom niet verwonderlijk dat er onder andere op internet een levendige discussie op gang is gekomen over de invoering ervan. Opvallend is echter dat in die discussie (wetenschappelijke) onderbouwing veelal ontbreekt. Daarnaast wordt er voorbij gegaan aan het feit dat het idee van de beroepseed voor accountants niet nieuw is. De discussie rondom het accountantsberoep is in Nederland namelijk ruim een eeuw geleden al gevoerd door de leden van de voorloper van de NBA, het Nederlands Instituut van Accountants (NIVA). Met dit artikel wordt beoogd het accountantsverleden rondom de beroepseed nader te belichten en tevens de leemtes in het publieke debat in te vullen door naar voren gebrachte argumenten nader te onderbouwen met juridische literatuur. Zo wordt getracht te achterhalen of een beroepseed voor accountants meerwaarde biedt. Om tot een antwoord op deze vraag te komen zal in paragraaf 2 de discussie die startte in 2014 rondom de totstandkoming van de beroepseed besproken worden. Hierbij wordt beoogd een impressie te geven van de publieke discussie, waarbij de meest in het oog springende argumenten expliciet zullen worden benoemd. Er wordt niet gepoogd een uitputtend overzicht van alle argumenten uit de publieke discussie weer te geven. In paragraaf 3 worden - aan de hand van drie wetsvoor- 
stellen - de pogingen besproken om de beroepseed voor accountants in de periode tussen 1900 en 1930 in Nederland in te voeren. Met behulp van veelal juridische literatuur wordt in paragraaf 4 onderbouwing gegeven aan de in de discussie naar voren gebrachte argumenten voor en tegen de beroepseed. Tevens zal de tekst van de beroepseed nader worden bezien. In de laatste paragraaf, paragraaf 5, wordt betoogd dat de beroepseed voor accountants in theorie meerwaarde kan bieden, maar in de praktijk zijn waarde zal moeten bewijzen.

\section{De discussie over de beroepseed voor accoun- tants sinds 2014}

De huidige discussie over de beroepseed startte op 25 september 2014 met de publicatie van het rapport 'In het publiek belang'. Op de dag van publicatie kreeg het voornemen van de werkgroep 'Toekomst accountantsberoep' tot invoering van een beroepseed, als één van de 53 maatregelen, in de media weinig aandacht. In het NRC Handelsblad en door de NOS werd de beroepseed wel genoemd en daarbij zelfs geduid als één van de belangrijkste voorstellen (Van der Heijden, 2014; NOS 2014). Wanneer minister Dijsselbloem de accountantssector maant om de maatregelen uit het rapport 'In het publiek belang' te implementeren worden de maatregelen nader bezien (Kamerstukken II 2014/15, p.3). ${ }^{3}$ Het initiatief voor de invoering van de beroepseed ligt bij de NBA (Werkgroep 'Toekomst Accountantsberoep', 2014, p. 95).

Vanuit de beroepsgroep klinken gemengde geluiden over het nut van de invoering van een beroepseed. Zo volgt uit een peiling eind 2014 dat de meerderheid van de accountants de invoering van een beroepseed een slecht idee vindt en geeft onderzoek weer dat RA-studenten betwijfelen of de beroepseed leidt tot een meer betrouwbare accountant (De Bos, 2014; ESAA, 2014, p.4; Accountant.nl, 2014). De Bos (2014) benadrukt de positieve kant van de beroepseed wanneer hij stelt: "Een beroepseed benadrukt de fundamenten van een sterk en duurzaam accountantsberoep" (De Bos, 2014). Pheijffer geeft aan dat hij de beroepseed overbodig vindt omdat het accountantsberoep al een gedragscode kent die aan het tuchtrecht gekoppeld is. Hij ziet slechts meerwaarde in een 'eed' waarin de accountant verklaart uit zijn werkzaamheden geen mogelijke reputatieschade toebrengende zaken te kennen (Pheijffer, 2014a).

In het voorjaar van 2015 mengt de NBA zich in het publieke debat rond de beroepseed. Zo bepleit Van Arkel (2015) dat een beroepseed nodig is voor alle accountants om uitdrukkelijk te benadrukken en te bevestigen dat zij achter de regels en waarden van het beroep staan. Van Arkel stelt daarbij dat de tekst van de eed dicht moet aansluiten bij de bestaande gedrags- en beroepsregels. De opiniebijdrage van Van Arkel levert op Accountant.nl enkele tientallen reacties van lezers op, variërend van uitingen van instemming met de beroepseed - met bijbehorende tekstvoorstellen - tot afkeurende reacties waarin zorgen geuit worden over de toegevoegde waarde van de eed.

Vanuit de beroepsgroep zelf lijkt het vertrouwen in de eed niet zo groot, zo blijkt uit opmerkingen dat accountants zich waarschijnlijk niet aan de eed zullen houden (Van Kempen, 2015). Moling en Ham (2015) denken hier anders over. Zij stellen dat de beroepseed nuttig zou kunnen zijn doordat accountants na het afleggen van de eed wellicht niet alleen de wet naleven maar zich ook gaan afvragen of gedragingen maatschappelijk verantwoord en gewenst zijn. Daarom is het van belang, aldus Moling en Ham, dat uit de beroepseed duidelijk blijkt wat er beloofd wordt, zodat er geen ongerechtvaardigde verwachtingen rijzen (Moling \& Ham, 2015). Ook Bik (2015) en Van der Zijde (2015) laten zich positief uit over de beroepseed, al plaatsen zij beiden wel een kanttekening. Bik stelt dat de eed pas werkelijk van nut wordt wanneer deze wordt ingebed in de cultuur van de accountantsorganisatie en Van der Zijde benadrukt het belang van een externe toezichthouder bij de naleving van de eed. Onder accountancystudenten lopen de meningen rondom de invoering van de beroepseed sterk uiteen (Dekker, 2015, p. 17).

De discussie rondom de invoering van de beroepseed voor accountants is levendig. Dit bleek ook uit de peiling van de NBA van afgelopen zomer waarop veelvuldig werd gereageerd en waarin onder andere de voorkeur kon worden uitgesproken voor de tekst van de beroepseed (NBA, 2015). Twee derde van de respondenten gaf daarbij de voorkeur aan de volgende tekst:

"Ik ben mij ervan bewust dat ik als accountant handel in het algemeen belang. Ik oefen mijn beroep uit met een professioneel kritische instelling. In de uitoefening van mijn beroep als accountant laat ik mij leiden door fundamentele beginselen van integriteit, objectiviteit, vakbekwaamheid, zorgvuldigheid en vertrouwelijkheid. Ik houd mij aan de wetten en regelgeving die op mijn beroep van toepassing zijn. Mijn professionaliteit brengt met zich mee dat ik geen handelingen verricht waarvan ik behoor te weten dat die het accountantsberoep in diskrediet kunnen brengen. Dat zweer/beloof/verklaar ik."

Voor- en tegenstanders van de beroepseed laten van zich horen in de discussie rondom de beroepseed maar komen met weinig (wetenschappelijke) onderbouwing van hun argumenten. Ook het Nederlandse verleden van de beroepsgroep ontbreekt in de huidige discussie. Men lijkt te zijn vergeten dat ruim een eeuw geleden ook in 
het accountantsberoep in Nederland is nagedacht over de beroepseed. Voor argumenten voor of tegen de eed wordt wel verwezen naar andere beroepsgroepen als bankiers en artsen. Een vergelijking met deze beroepsgroepen valt echter buiten de scope van dit artikel. ${ }^{4}$

\section{De beroepseed vanuit historisch perspectief}

\subsection{Wetsvoorstel Nederlandsch Instituut voor Accountants}

Eind $19 \mathrm{e}$ eeuw kan geduid worden als de start van het accountantsberoep in Nederland (De Vries, 1985, p. 34 e.v.). Eenieder mocht zich destijds accountant noemen. Deze eerste accountants groepeerden zich en in 1895 is de eerste beroepsvereniging voor accountants in Nederland opgericht, het Nederlandsch Instituut voor Accountants (NIVA) (Sternheim, ca. 1935, p. 7-19). Eén van de doelstellingen van het NIVA was 'te streven naar eene wettelijke regeling van het beroep van Accountant als controleur van boeken en rekeningen, liquidateur en administratief expert'. In 1900 heeft het NIVA daarom een eerste wetsvoorstel tot regeling van het beroep van accountant opgesteld. Hierbij is een ontwerp van een memorie van toelichting (MvT) en een verzoekschrift aan de Koningin gestuurd met het verzoek om het voorstel aan de regering te geven zodat die het bij de Staten-Generaal kon indienen (NIVA, 1900a). De eerste vier artikelen van dit eerste Nederlandse wetsontwerp voor accountants zien op de beroepseed van de accountant (NIVA, 1900c). De opstellers van dit eerste wetsontwerp beoogden niet het gehele accountantsberoep wettelijk te regelen maar regels vast te stellen voor de accountantswerkzaamheden die vanuit de wet voortvloeiden (NIVA, 1900b). De reden hiervoor was dat personen die zichzelf aanduiden als accountant werkzaamheden uitvoerden die gedeeltelijk ook door niet-accountants, bijvoorbeeld boekhouders, uitgevoerd werden. Bij het volledig wettelijk regelen van het accountantsberoep zouden de in de wet opgenomen taken niet meer door niet-accountants uitgevoerd kunnen worden, hetgeen onwenselijk werd geacht.

In het geval dat er een wettelijke verplichting tot inschakelen van een accountant was zou er wel een kwalitatief goede accountant moeten komen: de beëdigd accountant. Om beëdigd te worden moest een accountant voldoen aan de opleidingsvereisten die genoemd werden in het wetsvoorstel, een verklaring omtrent gedrag kunnen overleggen en een positief advies hebben gekregen van de raad van toezicht. Na beëdiging zou de accountant ook onder toezicht van de raad van toezicht vallen zodat de kwaliteit van de accountant kon worden geborgd (NIVA, 1900c, artt. X-XXI). Die eed moest bij de arrondissementsrechtbank worden afgelegd. Uit de ontwerp-MvT volgt dat het opnemen van een beroepseed in het wetsontwerp van het NIVA een praktische reden had. De leden van het NIVA kregen in de praktijk regelmatig de vraag of zij beëdigd waren en hebben om die reden een eed in het wetsontwerp opgenomen (NIVA, 1900b). De tekst van de beroepseed voor accountants zoals voorgesteld door het NIVA is beknopt en luidt:

"Ik zweer (beloof) dat ik het beroep van accountant volgens de daarop vastgestelde wettelijke bepalingen naar mijn beste weten en vermogen zal uitoefenen en dat ik geen misbruik zal maken van mij in de uitoefening van mijn beroep ter kennis gekomen gegevens. Zoo waarlijk helpe mij God Almachtig! (Dat beloof ik!)".

\subsection{Commissie-Van Nierop}

Het door het NIVA ontwikkelde wetsvoorstel wordt een aantal keer besproken in de Tweede Kamer maar wordt uiteindelijk geen wet (De Vries, 1985, pp. 82-83). Ondertussen ontwikkelt het accountantsberoep in Nederland zich verder en neemt het een steeds belangrijkere plaats in Nederland in (Staatscommissie-Van Nierop, 1920, p. 75; De Vries, 1985, p. 96). Het belang van het instellen van een wettelijke regeling wordt steeds groter geacht. In 1918 wordt de eerste staatscommissie aangesteld die de opdracht krijgt te onderzoeken of er een regeling voor het handelsonderwijs en het accountantswezen behoort te worden getroffen. Deze commissie onder leiding van mr. F.S. van Nierop brengt in december 1920 haar onderzoeksbevindingen uit (Staatscommissie-Van Nierop, 1920).

Ook in dit wetsontwerp is de beroepseed vervat. De tekst van de eed is iets aangepast ten opzichte van het eerdere ontwerp van het NIVA. De nieuwe tekst luidt:

"Ik zweer (ik beloof) dat ik het beroep van accountant naar mijn beste weten en vermogen zal uitoefenen en dat ik aan niemand zal openbaren wat in die uitoefening als geheim mij is toevertrouwd of te mijner kennis is gekomen tenzij mijne verklaring als getuige in rechte gevorderd of ik anderszins tot het geven van mededeeling door de wet verplicht worde. Zoo waarlijk helpe mij God almachtig (dat beloof ik)".

In de ontwerp-MvT wordt over de beroepseed opgemerkt dat er voor de tekst van de eed is aangesloten bij die van de artsen (Staatscommissie-Van Nierop, 1920, p. 78). Een nadere toelichting hierop ontbreekt. Ook dit wetsontwerp leidt niet tot een daadwerkelijke wet. De jaren verstrijken en in 1928 wordt er wederom een staatscommissie ingesteld die dient te adviseren over een regeling van het accountantswezen. De commissie, voorgezeten door $\mathrm{mr}$. H. Bijleveld, brengt in maart 1930 verslag uit (Staatscommissie-Bijleveld, 1930).

\subsection{Commissie-Bijleveld}

Wederom was het de beroepsgroep zelf die aandrong op een wettelijke regeling. Den Nederlandschen Bond 
van Accountants, de Nederlandse Organisatie van Accountants en het NIVA, de drie oudste beroepsverenigingen van Nederland, hebben in onderlinge samenwerking een wetsvoorstel ingediend. Naar aanleiding daarvan is de Staatscommissie-Bijleveld ingesteld om dit voorstel te onderzoeken.

In het ontwerp van de samenwerkende beroepsverenigingen is de beroepseed nog te lezen en in tekst volledig gelijk aan het voorstel uit 1920 (StaatscommissieBijleveld, 1930, Bijlage V, pp. 86-87). De Commissie-Bijleveld besluit echter om het voorstel tot de invoering van de beroepseed niet te volgen. Door de commissie wordt opgemerkt dat hoewel het bij officieel geregelde beroepen in Nederland gebruikelijk is om een beroepseed af te leggen het nut ervan bij het accountantsberoep in twijfel wordt getrokken. Als reden hiervoor wordt aangedragen dat de uit de eed volgende verplichting tot geheimhouding ook in de wet geregeld kon worden. De Commissie-Bijleveld geeft aan het wettelijk regelen van de geheimhouding de voorkeur (Staatscommissie-Bijleveld, p. 15). De Ontwerpwet van de Commissie-Bijleveld krijgt veel kritiek, met name uit de hoek van de accountantsverenigingen die niet bij het ontstaan van het wetsontwerp betrokken zijn geweest (Bezwaren, 1930; Meijer, 1939). De kritiek ziet echter niet op de beroepseed voor accountants. En zo verdwijnt in 1930 het idee van de beroepseed voor accountants weer en duurt het een kleine eeuw voordat het accountantsberoep wederom discussieert over de invoering en tekst van de beroepseed.

\section{Waardering van de beroepseed voor accountants}

\subsection{Voor- en nadelen van een eed bezien vanuit de juridische literatuur}

Opvallend is dat zowel in het voorstel tot, als in de vroegere en huidige discussie over de beroepseed voor accountants de inhoudelijke discussie over de meerwaarde van de eed beperkt is. Zo merken Buijink en Dassen (2015) op dat in het rapport 'In het publiek belang' een bespreking van de maatregelen vanuit de (bedrijfs)economisch wetenschappelijke literatuur ontbreekt, een leemte die zij invullen. Door de nieuwheid van de beroepseed is het bedrijfseconomisch onderzoek nog beperkt. Desalniettemin concluderen Buijink en Dassen dat er aanwijzingen zijn voor een positief effect van de beroepseed. Tevens stellen zij dat het effect van de invoering van de eed lastig meetbaar zal zijn, gegeven de overige recente wijzigingen in het accountantsberoep en dat de verwachtingen over het effect van de eed daardoor verminderen (Buijink \& Dassen, 2015, p. 106).

De waarde van een eed is door Soeharno toegelicht in zijn oratie (2013). Hij benoemt drie kernmotieven van een eed, te weten gerechtigheid, geloofwaardigheid en cohesie, die gedrieën aanwezig moeten zijn om een eed zin of waarde te geven. De beroepseed voor accountants is in theorie van waarde wanneer voldaan wordt aan deze drie kernmotieven. Het kernmotief gerechtigheid ziet op de kenmerkende waarden van de professie, die voorrang verkrijgen op de eigen belangen van de professional. Volgens artikel 2 Verordening gedragsen beroepsregels accountants (VGBA) zijn de kernwaarden van het accountantsberoep de fundamentele beginselen: professionaliteit, integriteit, objectiviteit, vakbekwaamheid en zorgvuldigheid, en vertrouwelijkheid. Soeharno stelt dat een eed aan het motief geloofwaardigheid voldoet als duidelijk is wat onder de kernwaarden verstaan moet worden. Een eed zal er niet voor zorgen dat de professional zich bewust wordt van de kernwaarden. Het doel van de eed ligt erin dat de professional door het uitspreken of horen van de eed deze fundamentele beginselen van het beroep levendig voor de geest haalt. Indien de eed dit effect niet teweeg brengt, dan heeft de eed geen waarde. Het derde motief is cohesie; de eedaflegger treedt bij het uitspreken van de eed toe tot de 'eedgemeenschap'. De eedgemeenschap beseft - net als de eedaflegger - door het uitspreken van de eed dat zij samenhangt door de kernwaarden van de professie die eenieder bij het uitspreken van de eed aanvaart. Dit besef kan een gunstige uitwerking hebben op het morele gedrag van mensen. De negatieve kant van het afleggen van de eed is dat bij schending ervan niet alleen de eigen eer maar ook de kernwaarden van de eedgemeenschap op het spel worden gezet (Soeharno, 2013, pp. 21-25).

De invoering van de beroepseed voor accountants in Nederland is nieuw en daardoor is er, strikt genomen, nog geen eedgemeenschap. Bij invoering van de beroepseed is het creëren van deze eedgemeenschap een aandachtspunt. De beroepsgroep van accountants bestaat uit de personen die ingeschreven staan in het register van de NBA. Binnen deze homogene groep zijn drie ledengroepen te onderscheiden, te weten: de openbaar accountants, de intern en overheidsaccountants en de accountants in business. ${ }^{5} \mathrm{Ik}$ bepleit dat de huidige leden van de NBA met een permanente educatieverplichting, die tevens werkzaamheden in het vakgebied van de accountancy verrichten, eenmalig de beroepseed afleggen om zo formeel de eedgemeenschap te creëren. Hiermee wijk ik af van Pheijffer (2014b) die van mening is dat huidige leden de eed niet hoeven af te leggen. Twee derde van de respondenten van de door de NBA uitgevoerde peiling geeft aan dat huidige leden van de NBA de eed af dienen te leggen (NBA, 2015). Mijns inziens is het afleggen van de eed voor huidige leden echter enkel van waarde voor die leden die werkzaamheden in het vakgebied van de accountancy verrichten, waardoor bijvoorbeeld niet elke accountant in business verplicht zou moeten zijn tot het afleggen van de beroepseed. 
De Werkgroep 'Toekomst Accountantsberoep' (2014) stelt voor dat de beroepseed door accountants wordt afgelegd bij inschrijving in het register (Werkgroep 'Toekomst Accountantsberoep', 2014, p. 36). Dit maakt dat het vraagstuk rondom het afleggen van de beroepseed door huidige leden van de NBA slechts bij invoering van de beroepseed een aandachtspunt zal zijn. In lijn met Soeharno lijkt mij het eenmalig zelf uitspreken van de beroepseed voldoende want, bij een eed die voldoet aan de drie kernmotieven, zal elke nieuwe toetreder tot de eedgemeenschap de huidige leden herinneren aan de eed en de waarde ervan. Het uitspreken van de beroepseed kan bijdragen aan de cohesie, want door het uitspreken laten de eedafleggers aan beroepsgenoten en buitenstaanders zien achter de fundamentele beginselen van het beroep te staan. Tevens kan het uitspreken bijdragen aan de geloofwaardigheid doordat de eedaflegger de fundamentele beginselen weer eigen maakt. Hierdoor kan het formeel creëren van de eedgemeenschap van toegevoegde waarde zijn.

Tegenstanders van de eed betogen dat de invoering van de eed onwenselijk is omdat er dan ook toezicht op moet komen. ${ }^{6}$ Tevens wordt opgemerkt dat het accountantsberoep al tuchtrecht kent en dat een eed daardoor overbodig is. ${ }^{7}$ Deze argumentatie acht ik echter niet overtuigend. Een eed is geen nieuwe verbintenis, maar een bekrachtiging van een eerdere afspraak (Soeharno, 2013, p. 5). Bij een schending van de weten regelgeving zal daarmee ook sprake zijn van een schending van de eed. Het al bestaande tuchtrecht en toezicht zien op de onder de eed liggende verbintenissen. Soeharno stelt dat een eed personen die buiten het beroep staan kan helpen bij het verkrijgen van inzicht in de overtuigingen van de beroepsgroep (Soeharno, 2013 , p. 6). De eed staat als het ware symbool voor de afspraken binnen de beroepsgroep.

De eed en religie gaan, van oudsher, lastig samen (Centrum voor staatkundige vorming, 1955, p. 5; Ernste, 1895). Soeharno stelt echter dat de eed aan herijking onderhevig is. Werd vroeger religie als drijfveer voor een hoger ideaal gezien, in de huidige tijd wordt het religieuze aspect uit de eed vervangen door de professionele waarden van het beroep (Soeharno 2013, p. 22). Vanuit religieuze overtuigingen kan er bezwaar zijn tegen het afleggen van een eed. ${ }^{8}$ Het uitspreken van een verklaring of belofte in plaats van het afleggen van een eed komt hieraan tegemoet en doet, mijns inziens, niet af aan de waarde ervan. De waarde ligt immers in het beleven van de fundamentele beginselen van de professie en het ervaren van de binding door diezelfde beginselen. In de recent voorgestelde tekst van de beroepseed biedt de NBA ook aan haar leden de mogelijkheid tot het uitspreken van een verklaring of belofte.

\subsection{De tekst van de beroepseed nader bezien}

Het tekstvoorstel voor de beroepseed uit 1900 bevat twee onderdelen, ten eerste dat de accountant het beroep zoals dat in de wet omschreven is naar zijn beste kennis en kunde zal uitoefenen en ten tweede dat de accountant geen misbruik zal maken van de informatie die hij ontvangt. Het tekstvoorstel uit 1920 bevat dezelfde twee onderdelen, zij het tekstueel iets aangepast. Zo ontbreekt de expliciete aansluiting bij de wettelijke regeling en is de geheimhouding uitvoeriger opgeschreven. De expliciete aansluiting bij de wet- en regelgeving is in het meest recente publieke tekstvoorstel voor de beroepseed weer te zien. Daarnaast bevat deze conceptberoepseed vier andere onderdelen die zien op het bewustzijn van het handelen in het algemeen belang, de uitoefening van het beroep met een professioneel-kritische instelling, het laten leiden door de fundamentele beginselen van het beroep en het afzien van handelingen die het beroep in diskrediet kunnen brengen.

In de publieke discussie werd opgemerkt dat de tekst van de eed (te) dicht bij bestaande beroepsregelgeving ligt. ${ }^{9}$ En, in lijn hiermee, schrapte de Commissie-Bijleveld in 1930 de beroepseed uit het wetsvoorstel omdat de geheimhouding beter in de wet opgenomen kon worden. Soeharno stelt dat het uitspreken van een eed het bekrachtigen van een bestaande verbintenis is (Soeharno, 2013, p. 5). In de tekst van de eed kan dus geen nieuwe informatie staan omdat een eed geen zelfstandige verbintenis is. De opmerkingen uit de publieke discussie dat het tekstvoorstel van de eed dicht bij de tekst van de bestaande beroepsregelgeving ligt, is in dit licht bezien daarom een wenselijke observatie want dat geeft weer dat het voorstel voor de beroepseed in lijn is met het doel van een eed. Ook was het terecht dat de Commissie-Bijleveld de geheimhouding in de wet wilde opnemen en niet slechts in de eed. Het argument om de beroepseed te laten vervallen omdat de geheimhoudingsplicht in de wet opgenomen moet zijn overtuigt mij niet. Indien door middel van de tekst van de eed de geheimhoudingsplicht bekrachtigt wordt kan dit mijns inziens naast de in de wet opgenomen geheimhoudingsplicht bestaan.

Soeharno stelt dat elke eed in essentie neerkomt op de tekst "ik zweer dat ik integer zal zijn" (Soeharno, 2013, p. 23). 'Integriteit', tevens expliciet genoemd als één van de fundamentele beginselen van het accountantsberoep, is zichtbaar in elk van de drie tekstvoorstellen, waarmee elk kwalificeert als eed. De overige onderdelen van de eed zijn daardoor niet noodzakelijk, maar kunnen mijn inziens wel waarde toevoegen aan de eed. Zoals gezegd is een eed van waarde wanneer voldaan is aan de drie kernmotieven: gerechtigheid, geloofwaardigheid en cohesie, waarbij gerechtigheid ziet op de 
fundamentele beginselen van het beroep (Soeharno, 2013, pp. 21-25). Het expliciteren van die beginselen in de tekst van de eed kan bijdragen aan het ervaren van een groepsgevoel door het uitspreken van de gedeelde waarden maar, wellicht belangrijker, laat ook aan buitenstaanders zien wat de fundamentele beginselen van het accountantsberoep zijn. Dit geldt, zij het in mindere mate, ook voor het noemen van de professioneel-kritische instelling. Hoewel de professioneelkritische instelling een steeds belangrijkere rol in lijkt te nemen in het accountantsberoep, is het slechts een nadere invulling van de fundamentele beginselen (Werkgroep 'Toekomst accountantsberoep', 2014, p. 11). Want wat is een professioneel-kritisch accountant meer dan een accountant die professioneel, integer en vakbekwaam is?

De voorgestelde afsluiting van de beroepseed waarin het begrip 'professionaliteit' wordt toegelicht is, zo lijkt mij, van waarde omdat het bijdraagt aan het motief 'geloofwaardigheid'. De toelichting concretiseert het begrip 'professionaliteit' en draagt daardoor bij aan de beleving ervan. Het expliciet benoemen van het volgen van wet- en regelgeving vind ik daarentegen niet zo sterk. Ook in de beroepseed van 1900 werd dit aspect benoemd maar het heeft het voorstel uit 1920 niet gehaald. Het volgen van wet- en regelgeving is geen kern van het accountantsberoep, iedereen wordt geacht zich aan de wet te houden, en daarom past het mijn inziens niet bij het doel van de eed. Een eed bevat niet alle gemaakte afspraken maar is 'slechts' een bevestiging van de al gemaakte afspraken. Dat een accountant zich houdt aan wet- en regelgeving volgt al uit de kernbeginselen.

\section{Conclusie}

De beroepseed voor accountants komt er (NBA, 2015). De waarde van de eed zal in de praktijk moeten blij- ken. De literatuur laat zien dat een beroepseed van waarde kan zijn als voldaan is aan de drie kernmotieven. In de beroepseed voor accountants is het kernmotief gerechtigheid al vervat in de voorgestelde tekst van de beroepseed doordat de fundamentele beginselen van het beroep hierin expliciet zijn opgenomen. Hoewel er nog geen eedgemeenschap is, is er wel sprake van een afgebakende (beroeps)groep van accountants die zijn ingeschreven in het register. ${ }^{10}$ Dit geeft al een eerste bijdrage aan het kernmotief cohesie. De beroepseed zal effect hebben op het hele accountantsberoep en velen hebben wellicht daarom de kans gegrepen om van zich te laten horen. Hieruit is, mijns inziens, al een aanzet van cohesie te zien doordat voor- en tegenstanders van de beroepseed door middel van het uiten van hun standpunt tevens laten zien zich betrokken te voelen bij de beroepsgroep. Rest het motief 'geloofwaardigheid'. Hier ligt een taak voor de beroepsorganisatie om de fundamentele beginselen van het beroep levendig te houden zodat elke accountant er zich een voorstelling bij kan maken. Tevens ligt hier een taak voor elke accountant, zij zijn het immers die de eed geloofwaardig moeten maken.
Mr. drs. E.V.A. Ejjkelenboom is als promovenda werkzaam bij Erasmus School of Law van de Erasmus Universiteit Rotterdam en verbonden aan het Instituut voor Ondernemingsrecht ('IvO') en het IvO Center for Financial Law \& Governance ('ICFG'). Zij verricht onderzoek naar de governance van accountantsorganisaties. De auteur bedankt mr. drs. A.A. Bootsma, mr. drs. R.E. van Lambalgen en de referenten van het MAB voor hun waardevolle opmerkingen en suggesties.

\section{Noten}

Zie www.accountant.n//toekomst/.

nttps://www.nba.n//Actueel/Nieuws/ Nieuwsarchief/NBA-monitor-accountants-grotendeels-op-schema-met-verbetermaatregelen/; berichtgeving in juni 2015.

3 De AFM wordt belast met het toezicht op de implementatie van de maatregelen door de accountantsorganisaties met een vergunning tot controle van de organisaties van openbaar be- lang (Kamerstukken II 2014/15, p.3).

Zie nader over de bankierseed themanummer van Tijdschrift voor Financieel Recht, 2014, nr. 6 en over de artseneed, Legemaate (2004).

5 Zie www.nba.n//Over-de-NBA/De-organisatie/Ledengroepen/.

6 Zie bijvoorbeeld de reacties op Van Arkel (2015).

Zie noot 6 .
Zie bijvoorbeeld de Bijbelteksten Mattheüs 5:33-37 en Jakobus 5:12.

Bii het tekstvoorstel voor de beroepseed dat Van Arkel (2015) doet wordt in de reacties opgemerkt dat dat nauw aansluit bij de beroepsregelgeving, waardoor het geen meerwaarde zou bieden.

10. Artikel 41 jo. 36 Wet op het accountantsberoep. 
- Accountant.nl (2014). Accountancystudenten: geen beroepseed, wel onderzoeksraad. Accountant.nl, 9 oktober 2014. Geraadpleegd op https://www.accountant.n//nieuws/2014/10/ accountancystudenten-geen-beroepseed-welonderzoeksraad/.

- AFM (2014). Uitkomsten onderzoek kwaliteit wettelijke controles Big 4-accountantsorganisaties. Amsterdam: Autoriteit Financiële Markten. Geraadpleegd op https://www.afm.nl/ nl-nl/nieuws/2014/sep/rapport-controlesbig4.

- Arkel, A.M. van (2015). Beroepseed voor accountants. Accountant.nl, 4 maart 2015. Geraadpleegd op: https://www.accountant.n// opinie/20151/3/beroepseed-vooraccountants/?ctx=switch-commentstake(5)?ctx=searchresultstake(30)\&search=true

- Bezwaren van het Algemeen Verbond van Accountants, het Nederl. Accountantsgenootschap, de Nederl. Associatie van Accountants, het Nederl. College van Accountants, het Ned. Genootschap van Accountants, de Nederlandsche Unie van Accountants, tegen het verslag der Commissie, ingesteld bij beschikking van den Minister van Arbeid, Handel en Nijverheid van 2 maart 1928, met de opdracht, van advies te dienen omtrent een regeling van het Accountantswezen (1930). Geraadpleegd op http://imagebase.ubvu.vu.nl/cdm/ref/collection/nib/id/811.

- Bik, 0. (2015). Over kippenvel gesproken. Accountant, 5(Q1): 44-49.

- Bos, A. de (2014). Eed voor accountants kan nut van goede cultuur bevestigen. Het Financieele Dagblad, 10 december 2014, p. 10.

- Buijink, W., \& Dassen, R. (2015). Bedrijfseconomie en de Werkgroep toekomst accountantsberoep 2014. Maandblad voor Accountancy en Bedriffseconomie, 89(3): 102-111.

- Centrum voor staatkundige vorming (1955). Wettelijke voorschriften betreffende de Eed: Wenselijkheid van herziening. Geraadpleegd op https://search.socialhistory.org/Record/482921.

- Dekker, G. (2015). Je wilt gewoon goed werk leveren. Accountant, 5(Q2): 14-19.

- Eijkelenboom, E.V.A., \& Hijjink, J.B.S. (red.) (2014). Bouwen aan vertrouwen: Evaluatie van de Wet toezicht accountantsorganisaties (Wta). Den Haag: Boom Juridische Uitgevers.

- Ernste, G.W. (1895). Eed of verklaring (dissertatie, Universiteit van Amsterdam). Amster- dam: H. Eisendrath.

- ESAA (2014). Resultaten eerste ESAA accountantspanel: Vertrouwen in de accountant. Erasmus School of Accounting \& Assurance, oktober 2014. Geraadpleegd op http://www. eur.n//fileadmin/ASSETS/esaa/documents/ Accountancy/ESAA-Rapport_Accountantspannel-okt_2014.pdf.

- Heijden, T. van der. (2014). Partners moeten de boeken voortaan weer zelf controleren. NRC Handelsblad, 25 september, p. 4.

- Kamerstukken II 2014/15, 33977, 2.

- Kempen, A. van (2015). De eed voor accountants. Accountant.nl, 1 juli 2015. Geraadpleegd op: https://www.accountant.n//opinie/20151/7/de-eed-voor-accountants/.

- Legemaate, J. (2004). De juridische implicaties van de Nederlandse artseneed. In: V. Kirkels (red.), Eed van Hippocrates. Nog van deze tijd? Nijmegen: Uitgeverij Valkhof Pers.

- Meijer, J. (1939). Het wetsontwerp tot regeling van het accountantswezen. Arnhem: G.W. van der Wiel \& Co.

- Moling, M., \& Ham, G. (2015). De eed: een alternatief voorstel. Accountant.nl, 3 juni 2015. Geraadpleegd op: https://www.accountant.n1/opinie/20151/6/de-eed-een-alternatief-voorstel/.

- NBA (2015). Accountants-eed: graag kort en bondig. Nederlandse Beroepsorganisatie van Accountants, 2 juli 2015. Geraadpleegd op: https://www.nba.nl/Actuee//Nieuws/Nieuwsarchief/Accountants-eed-graag-kort-en-bondig/.

- NIVA (1900a). Wet tot regeling van het beroep van accountant, verzoekschrift aan Hare Majesteit de Koningin, nr. 1. Nederlands Instituut van Accountants, augustus 1900.

- NIVA (1900b). Wet tot regeling van het beroep van accountant, Nota van toelichting tot het verzoekschritt, tevens memorie van toelichting tot het ontwerp van wet, nr. 2. Nederlands Instituut van Accountants.

- NIVA (1900c). Wet tot regeling van het beroep van accountant, ontwerp van wet, nr. 3. Nederlands Instituut van Accountants.

- NOS (2014). Accountants: veel mis bij ons, 25 september. Geraadpleegd op: http://nos.nl/ artikel/702488-accountants-veel-mis-bij-ons. html.

- Pheilffer, M. (2014a). Big four onder curatele en enige andere observaties. Accountant.nl, 30 september 2014. Geraadpleegd op: https:// www.accountant.n//opinie/2014/9/big-four-onder-curatele-en-enige-andere-observaties/.
- Pheilffer, M. (2014b). Eed voor oudgedienden: 'volstrekte lariekoek'. Accountant.nl, 1 juni 2015. Geraadpleegd op: https://www.accountant.n//opinie/20151/6/eed-voor-oudgedienden-volstrekte-lariekoek/.

- Soeharno, J.E. (2013). De waarde van de eed. Oratie Universiteit van Amsterdam. Amsterdam: Vossiuspers UvA.

- Staatscommissie Bijleveld (1930). Verslag der commissie, ingesteld bij beschikking van den minister van arbeid, handel en nijverheid van 2 maart 1928, met de opdracht, van advies te dienen omtrent eene regeling van het accountantswezen in: Verslagen en mededeelingen van de afdeeling handel en nijverheid van het departement van arbeid, handel en nijverheid jaargang 1930, nummer 2. 's-Gravenhage: Algemeene Landsdrukkerij.

- Staatscommissie Van Nierop (1920). Verslag van de staatscommissie benoemd bij koninklijk besluit van 16 mei 1918, no. 72, met opdracht na te gaan of - en zoo ja, op welke wijze - eene wettelijke regeling van het handelsonderwijs en het accountantswezen behoort te worden getroffen, met bepaling dat het door haar daaromtrent uit te brengen verslag vergezeld zal gaan van een beredeneerd voorstel, bevattende de uitwerking van hare denkbeelden in den vorm van een of meer ontwerpen van wet. Rotterdam: Drukkerij J. de Jong.

- Sternheim, A. (ca. 1935). Veertig jaren accountancy. In: Gedenkboek Nederlandsch Instituut van Accountants 1895-1935 (pp. 7-59). Geraadpleegd op http://imagebase. ubvu.vu.nl/cdm/ref/collection/nib/id/1452.

- Vries, J. de (1985). Geschiedenis der accountancy in Nederland: Aanvang en ontplooiing, 1895 - 1935. Assen/Maastricht: Van Gorcum.

- Werkgroep 'Toekomst accountantsberoep' (2014). In het publiek belang: Maatregelen ter verbetering van de kwaliteit en onafhankelijkheid van de accountantscontrole. Amsterdam: Nederlandse Beroepsorganisatie van Accountants. Geraadpleegd op: https://www.nba.n// Documents/Nieuws/2014/pdfs/ln\%20het\%20 publiek\%20belang\%20rapport\%20WG\%20 Toekomst\%20Acc\%2025sep14.pdf.

- Zijde, M. van der (2015). Te optimistisch. Accountant.nl, 21 juli 2015. Geraadpleegd op https://www.accountant.n//opinie/20151/7/ te-optimistisch/?ctx=author-15465. 